\title{
Vasorelaxation in rat pulmonary artery induced by the monoterpene thymol: evaluation of the endothelium derived relaxant factors dependence
}

\author{
Vasorrelaxamento em artéria pulmonar de rato induzido pelo monoterpeno timol: avaliação da \\ dependência de fatores relaxantes derivados do endotélio \\ Vasorrelajación en la arteria pulmonar de rata inducida por timol monoterpeno: evaluación de la \\ dependencia de los factores relajantes derivados del endotelio
}

Received: 03/16/2021 | Reviewed: 03/26/2021 | Accept: 04/01/2021 | Published: 04/11//2021

Renata de Souza Sampaio

ORCID: https://orcid.org/0000-0001-7066-5540 Universidade Federal da Paraíba, Brazil

E-mail: re.natinhasampaio@hotmail.com

Giuliana Amanda de Oliveira

ORCID: https://orcid.org/0000-0003-4981-6812 Universidade Federal da Paraíba, Brazil E-mail: giulianaamanda@hotmail.com

Luiz Henrique César Vasconcelos ORCID: https://orcid.org/0000-0003-0161-4891 Universidade Federal da Paraíba, Brazil E-mail: lhcv@academico.ufpb.br

Paula Benvindo Ferreira

ORCID: https://orcid.org/0000-0003-0158-5808 Universidade Federal da Paraíba, Brazil E-mail: paulabenvindo92@hotmail.com

Maria da Conceição Correia Silva ORCID: https://orcid.org/0000-0002-1041-9521 Universidade Federal da Paraíba, Brazil E-mail: ceicafarma@gmail.com Josean Fechine Tavares ORCID: https://orcid.org/0000-0003-0293-2605 Universidade Federal da Paraíba, Brazil E-mail: joseanfechine@yahoo.com.br

Fabiana de Andrade Cavalcante ORCID: https://orcid.org/0000-0002-5462-9459 Universidade Federal da Paraíba, Brazil E-mail:fa_cavalcante@hotmail.com

Bagnólia Araújo da Silva

ORCID: https://orcid.org/0000-0001-6926-482X Universidade Federal da Paraíba, Brazil E-mail:bagnoliasilva@yahoo.com.br

\begin{abstract}
Thymol and carvacrol are the main compounds found in Lippia mycrophylla essential oil (LM-OE) and have presented some spasmolytic effects. This work was designed to explore a possible vasorelaxant effect of LM-OE and its major monoterpenes constituents on rat pulmonary artery. For that, the organ was in vitro stimulated with phenylephrine (Phe) $3 \mu \mathrm{M}$ and over the tonic contraction the relaxant effect of LM-OE, carvacrol and thymol was observed in both intact and denuded-endothelium. Moreover, atropine, L-NAME, indomethacin, 2,3-O-isopropylidene adenosine, H-89 and Y-27632 were incubated before the relaxant curve of thymol over Phe-tonic contraction. Furthermore, the effects of thymol on $\mathrm{KCl} 30$ or $80 \mathrm{mM}$ and S-(-)-Bay K8644-induced tonic contractions were evaluated, as well as its inhibitory effect on $\mathrm{CaCl}_{2}$-induced cumulative contractions. LM-OE, carvacrol and thymol presented relaxant effect on pulmonary artery, thymol was the most potent and its relaxant potency in intactendothelium preparations was reduced by atropine, L-NAME, indomethacin, 2,3-O-isopropylidene adenosine and $\mathrm{H}-$ 89 , despite there was not change on its maximum relaxat effect. Also, the monoterpene relaxed equipotently $\mathrm{KCl} 30$ or $80 \mathrm{mM}$ pre-contracted pulmonary artery, antagonized $\mathrm{CaCl}_{2}$-induced cumulative contractions and relaxed S- $(-)$-Bay K8644 pre-contracted organ. Ultimately, thymol relaxant potency was not modified by Y-27632. Therefore, thymol acts by endothelium-dependent and independent mechanisms, possibly positively modulating the endothelial cholinergic pathway, prostanoids release and further activation of AC/PKA and also inhibiting $\mathrm{Ca}^{2+}$ influx through Cav.
\end{abstract}


Keywords: Pulmonary artery; Vasorelaxation; Thymol; Adenylyl cyclase; Voltage-gated calcium channels.

\begin{abstract}
Resumo
Timol e carvacrol são os principais compostos encontrados no óleo essencial de Lippia mycrophylla (LM-OE) e apresentam atividade espasmolítica. Este trabalho foi desenvolvido a fim de explorar um possível efeito vasorrelaxante do LM-OE e seus constituintes majoritários sobre artéria pulmonar de ratos. Para tanto, o órgão foi estimulado in vitro com fenilefrina (Phe) $3 \mu \mathrm{M}$ e, sobre a contração tônica, LM-OE, carvacrol e timol foram adicionados de maneira cumulativa, na ausência ou na presença de endotélio. Além disso, o efeito relaxante do timol foi avaliado na presença de atropina, L-NAME, indometacina, 2,3-O-isopropilideno adenosina, H-89 e Y-27632. Ademais, os efeitos do timol sobre as contrações tônicas induzidas por $\mathrm{KCl} 30$ ou $80 \mathrm{mM}$ e S-(-)-Bay K8644, bem como seu efeito inibitório nas contrações cumulativas induzidas por $\mathrm{CaCl}_{2}$. $\mathrm{LM}-\mathrm{OE}$, carvacrol e timol apresentaram efeito relaxante na artéria pulmonar, sendo o timol o mais potente. Sua potência relaxante em preparações com endotélio intacto foi reduzida pela atropina, L-NAME, indometacina, 2,3-O-isopropilideno adenosina e H-89, sem alteração do seu efeito relaxante máximo. Além disso, o monoterpeno relaxou de maneira equipotente a artéria pulmonar pré-contraída por $\mathrm{KCl} 30$ ou $80 \mathrm{mM}$, antagonizou as contrações cumulativas induzidas por $\mathrm{CaCl}_{2}$ e relaxou o órgão pré-contraído por S-(-)-Bay K8644. Em última análise, a potência relaxante do timol não foi modificada por Y-27632. Portanto, o timol atua por mecanismos dependentes e independentes do endotélio, possivelmente modulando positivamente a via endotelial colinérgica, liberação de prostanoides e posterior ativação da via AC/PKA, bem como inibindo o influxo de $\mathrm{Ca}^{2+}$ pelo $\mathrm{Cav}$.
\end{abstract}

Palavras-chave: Artéria pulmonar; Vasorrelaxamento; Timol; Adenilil ciclase; Canais de cálcio dependentes de voltagem.

\title{
Resumen
}

Timol y carvacrol son los principales compuestos que se encuentran en el aceite esencial de Lippia mycrophylla (LMOE) y tienen actividad espasmolítica. Este trabajo se desarrolló con el fin de explorar un posible efecto vasorrelajante de LM-OE y sus principales constituyentes en la arteria pulmonar de ratas. Para ello, el órgano se estimuló in vitro con fenilefrina (Phe) $3 \mu \mathrm{M}$ y, en la contracción tónica, se añadieron de forma acumulativa LM-OE, carvacrol y timol, en ausencia o presencia de endotelio. Además, se evaluó el efecto relajante del timol en presencia de atropina, LNAME, indometacina, 2,3-O-isopropilideno adenosina, H-89 e Y-27632. Además, los efectos del timol sobre las contracciones tónicas inducidas por $\mathrm{KCl} 30$ u $80 \mathrm{mM}$ y S-(-)-Bay K8644, así como su efecto inhibidor sobre las contracciones acumulativas inducidas por $\mathrm{CaCl}_{2}$. $\mathrm{LM}-\mathrm{OE}$, carvacrol y timol tuvieron efecto relajante sobre la arteria pulmonar, siendo timol el mas poderoso. Su potencia relajante en preparaciones con endotelio intacto se redujo con atropina, L-NAME, indometacina, 2,3-O-isopropilideno adenosina y H-89, sin alterar su máximo efecto relajante. Además, el monoterpeno relajó la arteria pulmonar precontraída por $\mathrm{KCl} 30$ u $80 \mathrm{mM}$, antagonizó las contracciones acumulativas inducidas por $\mathrm{CaCl} 2$ y relajó el órgano precontraído por S-(-)-Bay K8644. Finalmente, el poder relajante del timol no fue modificado por Y-27632. Por tanto, el timol actúa mediante mecanismos dependientes e independientes del endotelio, posiblemente modulando positivamente la vía endotelial colinérgica, la liberación de prostanoides y la posterior activación de la vía AC/PKA, así como inhibiendo el influjo de $\mathrm{Ca}^{2+}$ por $\mathrm{Ca}_{\mathrm{v}}$.

Palabras clave: Arteria pulmonar; Vasorrelajación; Timol; Adenilil ciclasa; Canales de calcio dependientes del voltaje.

\section{Introduction}

The use of plants for therapeutic purposes is one of the oldest forms of medicinal practice of humanity (Marques; Filgueiras, 2009). Lippia microphylla Cham., found only in Guyana and Brazil, popularly known as "alecrim do mato", "alecrim de tabuleiro" and "alecrim pimenta", has presented some pharmacological activities for its essential oil LM OE or the major compounds thymol and carvacrol, position isomers monoterpenes (Agra; Freitas; Barbosa-Filho, 2007; Rodrigues et al., 2011), highlighting antibacterial against Staphylococus aureus (Rodrigues et al., 2011), antitumoral (Xavier et al., 2011), spasmolytic in guinea pig stomach and vena portae (Beer; Lukanov; Sagorchev, 2007), trachea (Boskabady; Jafari; Pouraboli, 2011), and vasorelaxant in rat aorta (Peixoto-Neves et al., 2010).

The pulmonary artery is characterized as a thin, elastic vessel that branches to supply the various arteries of the pulmonary lobe, pulmonary arterioles and alveolar capillaries to promote pulmonary gas exchange (Singhal et al., 1973; Greyson, 2010; Zahid et al., 2020). Comparing with other vascular beds, the pulmonary circulation presents some particularities, being a system of low resistance and presenting different pattern of mediators and receptors, such as endothelin, endothelial nitric oxide synthase and prostanoids, acting itself as a system of own and differentiated functioning of the 
systemic circulation (Sommer et al., 2020; Wang et al., 2021).

Several pathological processes may result in acute or chronic increases in the afterload in the right ventricle, such as pulmonary arterial hypertension. As excess afterload increases, right heart failure may occur and sudden hemodynamic instability and death may occur (Greyson, 2010; Huang et al., 1996; Sommer et al., 2020; Zahid et al., 2020). Therefore, substances that relax smooth muscle of the pulmonary vascular bed can lead to a decrease in the afterload of the right ventricle and decreased symptoms of diseases, such as pulmonary arterial hypertension (PAH).

Accordingly, the pulmonary hypertension still has a lack of information about its pathophysiology and therapeutics, being responsible for high mortality worldwide (Lau et al., 2017). Therefore, this work was conceived in the hypothesis of a possible relaxant effect of LM-OE, thymol and carvacrol in healthy rat pulmonary artery and then further characterize the action mechanism as part of our research for new therapeutic candidates for the treatment of cardiopulmonary and circulatory disorders.

\section{Methodology}

\subsection{Animals}

Male Wistar rats (Rattus norvegicus), weighing 270-310 g, were obtained from the animal Animal Production Unit of the Instituto de Pesquisa em Fármaco e Medicamentos (IPeFarM) of Federal University of Paraíba (UFPB). The animals had access to water and food $\left(\right.$ Labina $\left.^{\circledR}\right)$ ad libitum, were kept in rooms at $21 \pm 1{ }^{\circ} \mathrm{C}$ and were subjected to a $12 \mathrm{~h}$ light-dark cycle (light from 6 to 18h00). All animal welfare and experimental procedures were undertaken following the Guidelines for the ethical use of animals in applied ethology studies (Sherwin et al., 2003) and were approved by the Ethics Committee on Animal Use (CEUA) of Federal University of Paraíba (UFPB) on July 16, 2013 by the certification number 0501/13.

\subsection{Chemicals}

The species Lippia microphylla Cham. was collected in June 2010 in the municipality of Serra Branca, state of Paraíba, Brazil, and the botanical material was identified by Maria de Fátima Agra, Ph.D., from Botany sector of UFPB. An exsiccate is deposited at the Herbarium Prof. Lauro Pires Xavier (JPB) of UFPB under identification code AGRA 6118.

The LM-OE was obtained and characterized by GC-MS (Xavier et al., 2011), and its major compounds carvacrol and thymol (purity $\geq 99,5 \%$ ) were obtained from Sigma-Aldrich (Brazil).

Also, acetylcholine hydrochloride $(\mathrm{ACh})$, Atropine, castor oil $\left(\right.$ Cremophor $\left.^{\circledR}\right)$, indomethacin, $\mathrm{N}^{\omega}$-nitro-L-arginine methyl ester (L-NAME), phenylephrine (Phe), S-(-)-Bay K8644, Y-27632 and 2',3'-O-isopropylidene adenosine (IPA) were obtained from Sigma-Aldrich (Brazil); forskolin and N-[2-(p-bromocinnamylamino)ethyl]-5-isoquinolinesulfonamide (H-89) were purchased from Cayman Chemical Company (USA). All substances were dissolved and diluted in distilled water, except H-89, IPA, S-(-)-Bay K8644 and Y-27632, which were dissolved in ethanol, and maintained cold under $-20{ }^{\circ} \mathrm{C}$. The compounds LM-OE, carvacrol and thymol were dissolved in distilled water and the surfactant Cremophor EL ${ }^{\circledR}$. The surfactant and ethanol concentration never exceeded $0.01 \%(\mathrm{v} / \mathrm{v})$ in the organ baths, resulting in no observable solvent effects on smooth muscle tone (unpublished data).

The concentrations of thymol and carvacrol in the organ baths were expressed in $\mu \mathrm{g} / \mathrm{mL}$ for better compare to the effect produced by the LM-OE.

\subsection{Pulmonary artery preparation and responsiveness analysis}

Rats were euthanized by guillotine decapitation, the heart and lungs were dissected from the thoracic cavity, the pulmonary arteries were isolated, cleaned of connective and adipose tissue and suspended in organ baths containing 
Krebs-Henseleit solution (composition, $\mathrm{mM}$ : $\mathrm{NaCl}, 119.0 ; \mathrm{KCl}, 4.6 ; \mathrm{MgSO}_{4}, 1.2 ; \mathrm{KH}_{2} \mathrm{PO}_{4}, 1.2 ; \mathrm{CaCl}_{2}, 1.5$; Glucose, 11.4 and $\mathrm{NaHCO}_{3}, 20.0$ ). The segments ( 2 to $3 \mathrm{~mm}$ ) were individually suspended in organ baths (BOI-04 AVS, São Paulo/SP, Brazil) connected to isometric force transducers (TIM-05 AVS, São Paulo/SP, Brazil), maintained under a resting tension of $1 \mathrm{~g}$, at $37{ }^{\circ} \mathrm{C}$ and bubbed with carbogen mixture $\left(95 \% \mathrm{O}_{2}\right.$ and $\left.5 \% \mathrm{CO}_{2}\right)$ (Pauvert et al., 2003).

Each preparation was equilibrated for $60 \mathrm{~min}$, then a stimulus with Phe $3 \mu \mathrm{M}$ was induced and over the tonic contraction (of amplitude equal to or greater than $0.5 \mathrm{~g}$ ), acetylcholine (ACh) $1 \mu \mathrm{M}$ was added to verify the endothelium integrity (Furchgott; Zawadzki, 1980). Vascular endothelium was considered intact when the ACh-induced relaxation was $>60 \%$ of the Phe-induced contraction. When the ACh-induced relaxation was $\leq 10 \%$, the preparations were considered without functional endothelium (Alencar et al., 2013).

The "n" value represents the number of rats from which the pulmonary artery was isolated for each experimental protocol.

\subsection{Effect of LM-OE, carvacrol and thymol on isolated rat pulmonary artery}

A stimulus was induced with Phe $3 \mu \mathrm{M}$ and, over the tonic contraction, the test products or forskolin (positive control) were cumulatively added in different preparations. Relaxation was expressed as the percentage of the reverse contraction induced by Phe, and compared based on maximum effect $\left(\mathrm{E}_{\mathrm{max}}\right)$, as efficacy parameter, and $\mathrm{EC}_{50}$ values (the concentration of a drug that provokes a response halfway between the baseline and maximum response) as potency parameter, obtained by non-linear regression from the concentration-response curves obtained for LM-OE, thymol and carvacrol in organ segments, in both intact and denuded endothelium (Alencar et al., 2013).

\subsection{Characterization of the mechanism of action of thymol in rat pulmonary artery}

2.5.1 Evaluation of the participation of endothelial muscarinic receptors $\left(\mathrm{M}_{3}\right)$, nitric oxide synthase (eNOS) and cyclooxygenase (COX) products

Intact endothelium pulmonary artery rings were pre-incubated with atropine $1 \mathrm{nM}$, a non-specific muscarinic receptor antagonist (Choy; Wong; Kwan, 2002); L-NAME 0.1 mM, a competitive inhibitor of NOS (Rees et al., 1990); or indomethacin $10 \mu \mathrm{M}$, inhibitor of COX (Subramani; Leo; Kathirvel, 2010), for $30 \mathrm{~min}$, in different preparations. Then, a stimulus was induced with Phe $3 \mu \mathrm{M}$ and, over the tonic contraction, thymol was added in cumulative concentrations. The thymol relaxant efficacy and potency were compared in both the absence and presence of the pharmacological tools.

\subsubsection{Effect of thymol on the adenylyl cyclase (AC) and protein kinase A (PKA) pathway}

Intact endothelium pulmonary artery rings were pre-incubated with IPA10 $\mu \mathrm{M}$, inhibitor of AC (Rodríguez-Ramos; González-Andrade; Navarrete, 2011); or H-89 0.5 $\mu \mathrm{M}$, inhibitor of PKA (Zhang et al., 2010), for $30 \mathrm{~min}$, in different preparations. Then, a stimulus was induced with Phe $3 \mu \mathrm{M}$ and, over the tonic contraction, thymol was added in cumulative concentrations. Thymol relaxant efficacy and potency were compared in both the absence and presence of inhibitors.

\subsubsection{Effect of thymol on $\mathrm{Ca}^{2+}$ influx through Cav1}

\subsubsection{Effect of thymol on pre-contracted pulmonary artery with 30 or $80 \mathrm{mM} \mathrm{KCl}$}

The pulmonary artery was stimulated with $\mathrm{KCl} 30$ and $80 \mathrm{mM}$, in different preparations, and over the tonic contraction, thymol was added in cumulative concentrations. Relaxation was expressed as the reverse percentage of the initial contraction induced by $\mathrm{KCl}$, and the efficacy and potency were compared between the two situations (Gurney, 1994). 


\subsubsection{Effect of thymol on $\mathrm{Ca}^{2+}$ influx through $\mathrm{Cav}$}

After the stabilization period, the Krebs-Henseleit solution was replaced by the depolarizing solution $(\mathrm{KCl} 80 \mathrm{mM})$ nominally $\mathrm{Ca}^{2+}$-free for a period of $45 \mathrm{~min}$. Following, two similar cumulative-concentrations curves to $\mathrm{CaCl}_{2}$ were obtained, referred as control. Then, thymol was incubated, in different concentrations and preparations, for 30 min, and a third contraction curve to $\mathrm{CaCl}_{2}$ was obtained. The contraction curves of $\mathrm{CaCl}_{2}$ in the presence of thymol was calculated based on the average amplitude of control contractions, and compared accordingly its $\mathrm{E}_{\max }$ and $\mathrm{EC}_{50}$ values in the absence and presence of the monoterpene (Karasu-Minareci et al., 2011).

\subsubsection{Effect of thymol on Cav1 channels}

After the stabilization period, the pulmonary artery was partially depolarized by addition of $\mathrm{KCl} 10 \mathrm{mM}$ for $10 \mathrm{~min}$, and a stimulus was induced with S-(-)-Bay K8644 $0.3 \mu \mathrm{M}$, a selective agonist of type $1 \mathrm{Cav}$. Over the tonic contraction, cumulative concentrations of thymol were added. $\mathrm{EC}_{50}$ values were obtained by non-linear regression from the concentrationresponse curve obtained for thymol and compared with its relaxant effect on Phe $3 \mu \mathrm{M}$ or $\mathrm{KCl} 80 \mathrm{mM}$ pre-contracted organ (Jeffery; Wanstall, 2011).

\subsubsection{Thymol activity in RhoA/Rho kinase (ROCK) pathway}

Intact endothelium pulmonary artery rings were pre-incubated with Y-27632 $1 \mu \mathrm{M}$, an ROCK inhibitor, for $30 \mathrm{~min}$. Then, a stimulus with Phe $3 \mu \mathrm{M}$ was induced and, over the tonic contraction, thymol was added in cumulative concentrations. The thymol relaxant potency was compared in both the absence and presence of the inhibitor (Gao et al., 2007).

\subsection{Statistical analysis}

The values were expressed as mean and standard error of mean (S.E.M.). Differences between values were statistically compared using Student's $t$-test, for single comparison, or one-way ANOVA followed by Tukey's post-test, for multiple comparisons, and were considered to differ significantly when $p<0.05$. All data were analyzed using GraphPad Prism software version 5.01 (GraphPad Software Inc., San Diego CA, USA).

\section{Results}

\subsection{Effect of LM-OE, carvacrol and thymol on isolated rat pulmonary artery}

LM-OE $(0.01-729 \mu \mathrm{g} / \mathrm{mL}, \mathrm{n}=5)$ completely relaxed the pulmonary artery rings pre-contracted with Phe $3 \mu \mathrm{M}$, in both intact and denuded endothelium, similarly to carvacrol $(0.01-243 \mu \mathrm{g} / \mathrm{mL}, \mathrm{n}=5)$; Otherwise, thymol $(0.01-243 \mu \mathrm{g} / \mathrm{mL}, \mathrm{n}=$ 5), that was more potent in intact endothelium pulmonary artery rings ( $<<0.05)$. $E_{\max }$ values were achieved with $729 \mu \mathrm{g} / \mathrm{mL}$ for LM-OE, $243 \mu \mathrm{g} / \mathrm{mL}$ for carvacrol and $243 \mu \mathrm{g} / \mathrm{mL}$ for thymol in the presence and absence of endothelium, respectively (Figure 1 and $2 \mathrm{~A}-\mathrm{C}$, Table 1$)$. Forskolin $\left(10^{-15}-10^{-11} \mathrm{M}\right)$, a standard drug to activate $\mathrm{AC}$, also relaxed the rat pulmonary artery rings pre-contracted by Phe $0.3 \mathrm{M}\left(\mathrm{E}_{\max }=100 \% ; \mathrm{EC}_{50}=5.6 \pm 0.6 \times 10^{-14} \mathrm{M}, \mathrm{n}=5\right)$ (Figure 2D). 
Figure 1 - Original records of the relaxing effect of LM-OE (A, B), carvacrol (C, D) and thymol (E, F) in rat pulmonary artery pre-contracted with $3 \mu \mathrm{M}$ Phe in intact $(\mathrm{A}, \mathrm{C}, \mathrm{E})$ and denuded endothelium $(\mathrm{B}, \mathrm{D}, \mathrm{F})$.

A

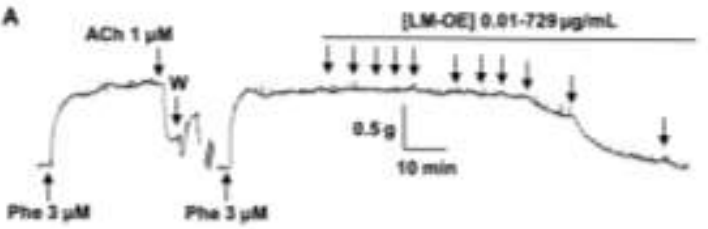

C
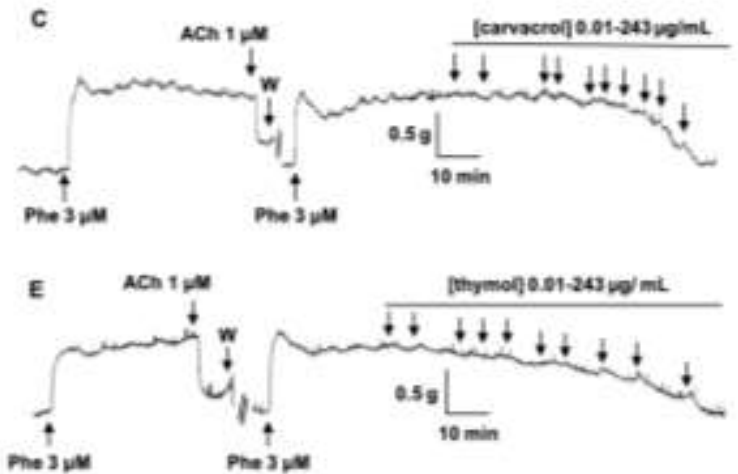

B
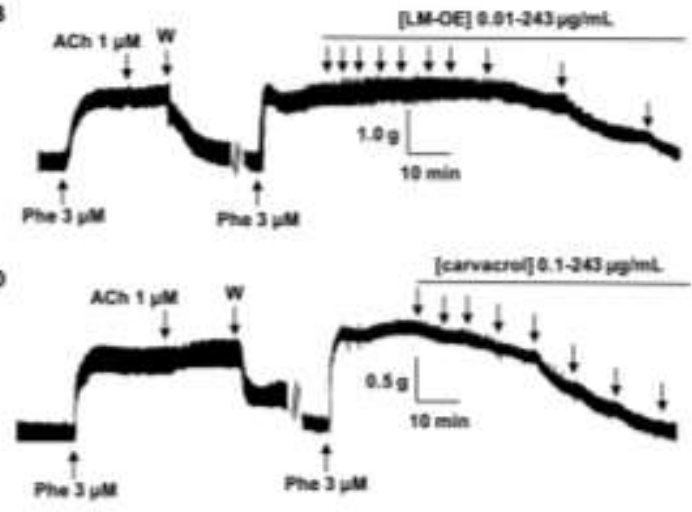

$\mathbf{F}$

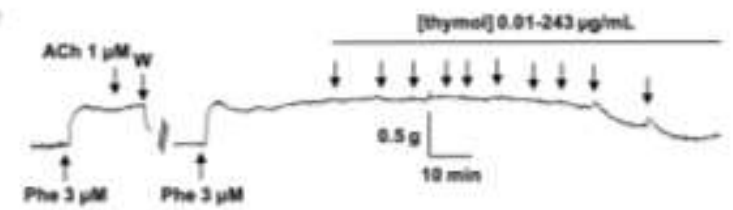

The down arrows below the bar represent the cumulative addition of LM-OE, carvacrol or thymol. Phe: phenylephrine; ACh: acetylcholine; W: washout.

Source: Authors (2021). 
Figure 2 - Relaxant effect of LM-OE (A), carvacrol (B) and thymol (C) on pre-contracted pulmonary artery rings with Phe 3 $\mu \mathrm{M}$ in both the presence and absence of intact endothelium, and of forskolin $(\mathbf{D})$ in the presence of endothelium.
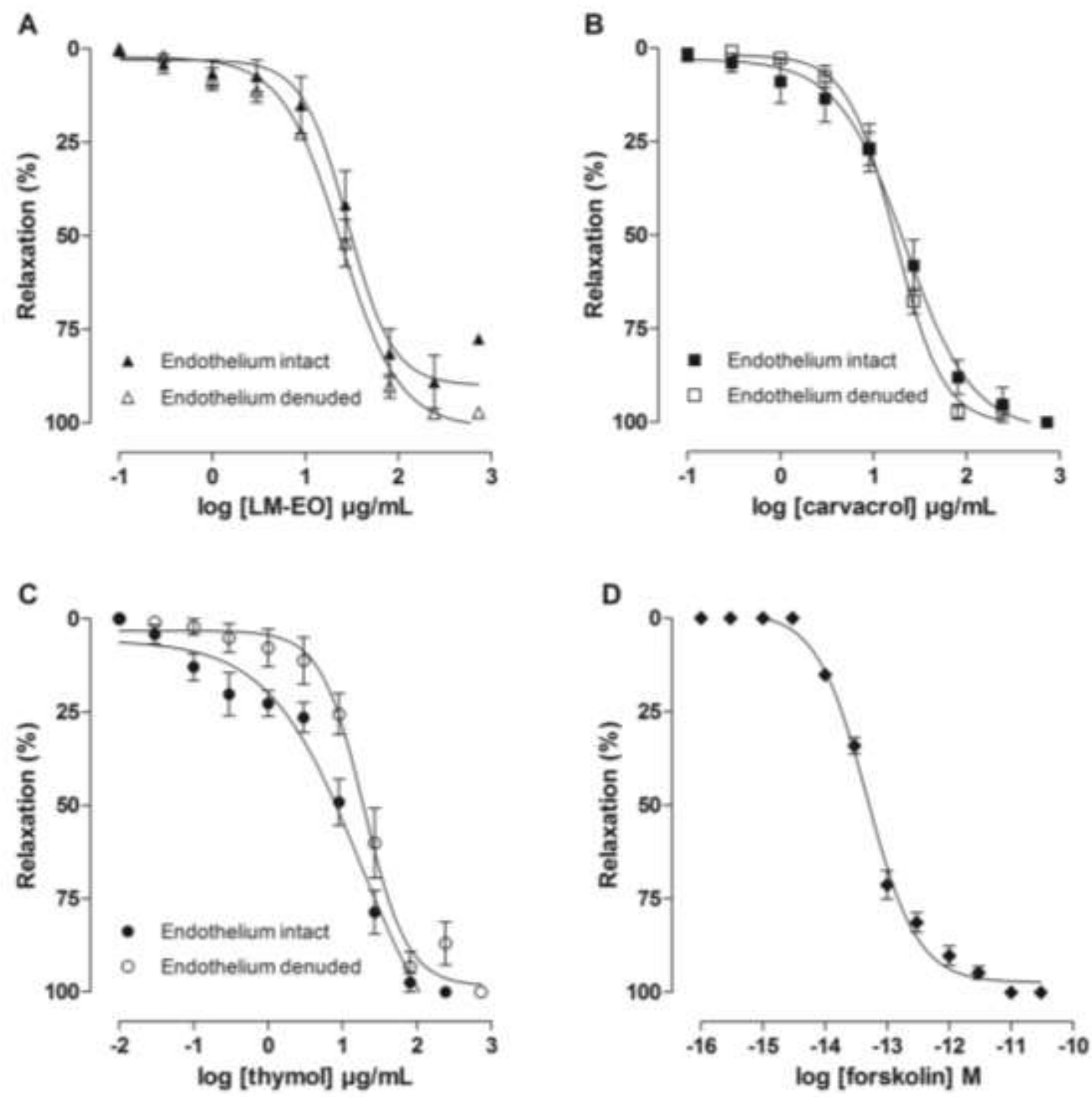

Data are expressed as the reverse percentage of maximal effect induced by phenylephrine. Symbols and vertical bars represent the mean and S.E.M, respectively $(n=5)$.

Source: Authors (2021).

Table $1-\mathrm{E}_{\max }(\%)$ and $\mathrm{EC}_{50}(\mu \mathrm{g} / \mathrm{mL})$ values of LM-OE, carvacrol and thymol in rat pulmonary artery pre-contracted with Phe $3 \mu \mathrm{M}$, in both the presence (E+) and absence (E-) of functional endothelium.

\begin{tabular}{ccccc}
\hline \multirow{2}{*}{ Products } & \multicolumn{2}{c}{$\mathbf{E}_{\max }(\%)$} & \multicolumn{2}{c}{ EC $\mathbf{5 0}_{\mathbf{5 0}}(\boldsymbol{\mu g} / \mathbf{m L})$} \\
\cline { 2 - 5 } & $\mathbf{E}(+)$ & $\mathbf{E}(-)$ & $\mathbf{E}(+)$ & $\mathbf{E}(-)$ \\
\hline LM-OE & $92.8 \pm 4.6$ & $97.8 \pm 0.9$ & $29.1 \pm 5.0$ & $21.8 \pm 1.9$ \\
Carvacrol & 100 & $97.3 \pm 2.0$ & $20.4 \pm 5.6$ & $15.8 \pm 1.0$ \\
Thymol & $99.6 \pm 0.4$ & 100 & $6.6 \pm 0.9 *$ & $23.02 \pm 3.8$ \\
\hline
\end{tabular}

Data expressed as mean and S.E.M, respectively $(\mathrm{n}=5)$. ANOVA one-way followed by Tukey post-test: ${ }^{*} p<0.05$ (thymol E+ vs. LM-OE E+/E-; carvacrol E+/E-; thymol E-).

Source: Authors (2021). 


\subsection{Characterization of the mechanism of action of thymol in rat pulmonary artery}

\subsubsection{Evaluation of the participation of endothelial muscarinic receptors $\left(M_{3}\right)$, nitric oxide synthase (eNOS) and} cyclooxygenase (COX) products

Thymol $(0.01-243 \mu \mathrm{g} / \mathrm{mL}, \mathrm{n}=5)$ relaxation curve was shifted to the right $(p<0.05)$ in the presence of atropine $1 \mathrm{nM}$, L-NAME $0.1 \mathrm{mM}$ and indomethacin $10 \mu \mathrm{M}$, being 4-, 2- and 4-fold, respectively, less potent to relax the rat pulmonary artery pre-contracted by $3 \mu \mathrm{M}$ Phe in the presence of these inhibitors, as indicated by the $\mathrm{EC}_{50}$ values (Figure 3, Table 2).

Figure 3 - Relaxant effect of thymol on isolated rat pulmonary artery rings pre-contracted with Phe $3 \mu \mathrm{M}$ in both the absence $(\bullet)$ and presence of atropine $(\square)$, L-NAME $(\triangle)$ or indomethacin $(\bullet)$.

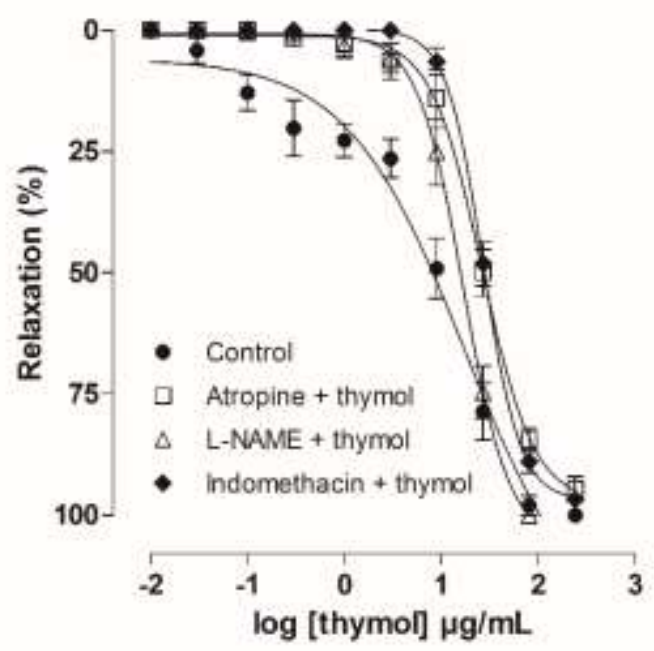

Data are expressed as the reverse percentage of maximal effect induced by phenylephrine. Symbols and vertical bars represent the mean and S.E.M, respectively $(\mathrm{n}=5)$.

Source: Authors (2021).

Table $2-\mathrm{E}_{\max }(\%)$ and $\mathrm{EC}_{50}(\mu \mathrm{g} / \mathrm{mL})$ values of thymol in rat pulmonary artery pre-contracted with Phe $3 \mu \mathrm{M}$, in the absence (control) and presence of atropine, L-NAME, indomethacin, IPA, H-89 and Y-27632.

\begin{tabular}{ccc}
\hline Thymol & $\mathbf{E}_{\max }(\boldsymbol{\%})$ & $\mathbf{E C}_{\mathbf{5 0}}(\boldsymbol{\mu g} / \mathbf{m L})$ \\
\hline Absence (control) & $99.6 \pm 0.4$ & $6.6 \pm 0.9$ \\
Atropine & 100 & $27.1 \pm 3.7^{*}$ \\
L-NAME & 100 & $14.7 \pm 1.2^{*}$ \\
Indomethacin & 100 & $27.7 \pm 2.6^{*}$ \\
IPA & $85.7 \pm 5.2^{*}$ & $18.0 \pm 1.0^{*}$ \\
H-89 & 100 & $13.7 \pm 1.3^{*}$ \\
Y-27632 & 100 & $10.1 \pm 2.1$ \\
\hline
\end{tabular}

Data expressed as mean and S.E.M, respectively $(\mathrm{n}=5)$. ANOVA one-way followed by Tukey post-test: ${ }^{*} p<0.05$ (control $v s$. atropine/L-NAME/indomethacin/IPA/H-89).

Source: Authors (2021). 


\subsubsection{Effect of thymol on the adenylyl cyclase (AC) and protein kinase A (PKA) pathway}

Thymol $(0.01-243 \mu \mathrm{g} / \mathrm{mL}, \mathrm{n}=5)$ relaxation curve was shifted to the right $(p<0.05)$ in the presence of IPA $10 \mu \mathrm{M}$ or H-89 $0.5 \mu \mathrm{M}$. The thymol relaxant potency was about 3- and 2-fold lower in the presence of these inhibitors, as can be seen by its $\mathrm{EC}_{50}$ values. In addition, thymol efficacy was also reduced by IPA (Fig. 4, Table 2).

Figure 4 - Relaxant effect of thymol on isolated pulmonary artery rings pre-contracted Phe $3 \mu \mathrm{M}$ in the absence $(\bullet)$ and presence of IPA $(\bullet)$ or H-89 $(\diamond)$.

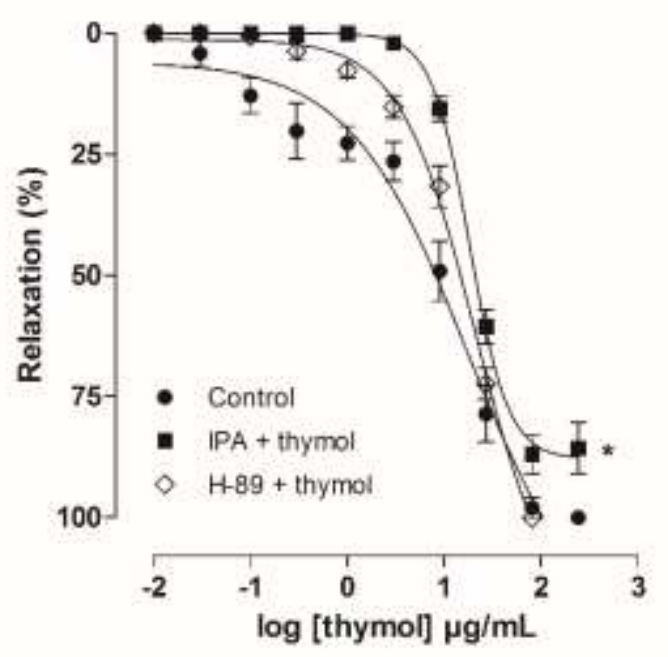

Data are expressed as the reverse percentage of maximal effect induced by phenylephrine. Symbols and vertical bars represent the mean and S.E.M, respectively $(\mathrm{n}=5)$. One-way ANOVA followed by Tukey's post-test. ${ }^{*} p<0.05$ (control $v s$. IPA + thymol).

Source: Authors (2021).

\subsubsection{Effect of thymol on $\mathrm{Ca}^{2+}$ influx through Cav1}

\subsubsection{Effect of thymol on pre-contracted pulmonary artery with 30 or $80 \mathrm{mM} \mathrm{KCl}$}

Thymol $(0.01-729 \mu \mathrm{g} / \mathrm{mL}, \mathrm{n}=5)$ showed an equipotent relaxant effect on rat pulmonary artery rings pre-contracted by $30\left(\mathrm{E}_{\max }=100 \% ; \mathrm{EC}_{50}=23.2 \pm 4.8 \mu \mathrm{g} / \mathrm{mL}\right)$ or $80 \mathrm{mM} \mathrm{KCl}\left(\mathrm{E}_{\max }=96.0 \pm 4.0 \% ; \mathrm{EC}_{50}=21.6 \pm 4.3 \mu \mathrm{g} / \mathrm{mL}\right)$ (Fig. 5). Based on the $\mathrm{EC}_{50}$ values, the thymol relaxant potencies did not differ statistically from each other when the organ was pre-contracted at moderate $(30 \mathrm{mM})$ or high $(80 \mathrm{mM}) \mathrm{KCl}$ concentrations. 
Figure 5 - Relaxant effect of thymol on isolated rat pulmonary artery rings pre-contacted with $\mathrm{KCl} 30(\boldsymbol{\nabla})$ or $80 \mathrm{mM}(\nabla)$. Data are expressed as the reverse percentage of maximal effect induced by $\mathrm{KCl}$.

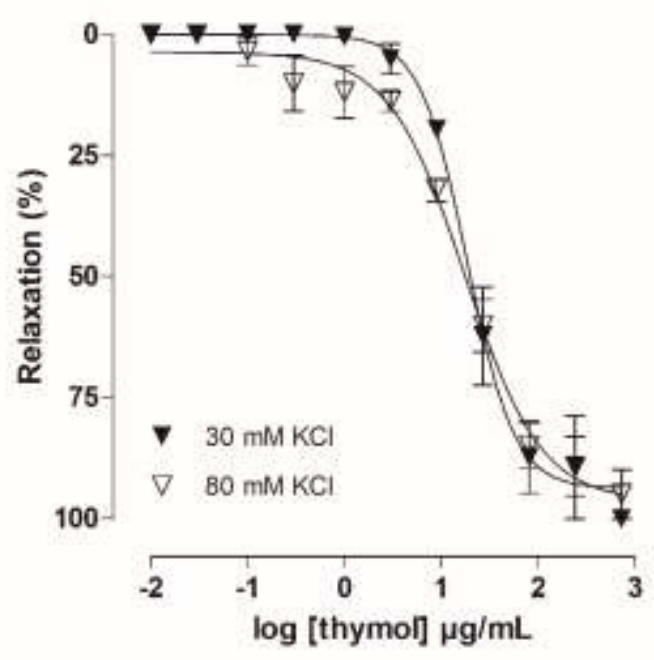

Symbols and vertical bars represent the mean and S.E.M, respectively $(\mathrm{n}=5)$.

Source: Authors (2021).

\subsubsection{Effect of thymol on $\mathrm{Ca}^{2+}$ influx through $\mathrm{Cav}$}

In a depolarizing medium $(\mathrm{KCl} 80 \mathrm{mM})$ nominally $\mathrm{Ca}^{2+}$-free, thymol $(3-81 \mu \mathrm{g} / \mathrm{mL}, \mathrm{n}=5)$ inhibited $(\mathrm{p}<0.05)$ $\mathrm{Ca}^{2+}$-induced contractions in a concentration-dependent manner by decreasing the $\mathrm{E}_{\max }$ and promoted a rightward shift of $\mathrm{CaCl}_{2}$ concentration-response curve only in a concentration of $27 \mu \mathrm{g} / \mathrm{mL}$, compares to control. $\mathrm{E}_{\max }$ of Ca ${ }^{2+}$ was completely abolished by thymol at the concentration of $81 \mu \mathrm{g} / \mathrm{mL}$ (Figure 6 , Table 3).

Figure 6 - Cumulative concentration-response curves to $\mathrm{CaCl}_{2}$ in depolarizing medium nominally without $\mathrm{Ca}^{2+}$ in the absence $(\bullet)$ and presence of $3(\circ), 9(\boldsymbol{\square}), 27(\square)$ and $81 \mu \mathrm{g} / \mathrm{mL}(\boldsymbol{\Delta})$ of thymol. Data are expressed as the percentage of maximal effect induced by $\mathrm{CaCl}_{2}$ on control $(100 \%)$.

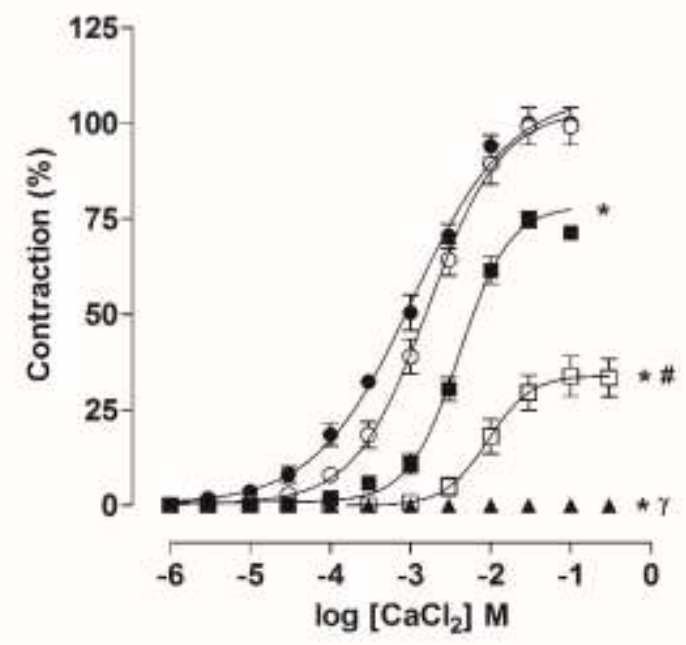

Symbols and vertical bars represent the mean and S.E.M, respectively $(\mathrm{n}=5)$. One-way ANOVA followed by Tukey's post-test. ${ }^{*} p<0.05$ (control vs. 9, 27 and $81 \mu \mathrm{g} / \mathrm{mL}$ thymol); ${ }^{\#} p<0.05\left(9 \mu \mathrm{g} / \mathrm{mL}\right.$ thymol $v s .27 \mu \mathrm{g} / \mathrm{mL}$ thymol); ${ }^{\#} p<0.05(27 \mu \mathrm{g} / \mathrm{mL}$ thymol $v s .81 \mu \mathrm{g} / \mathrm{mL}$ thymol).

Source: Authors (2021). 
Table $3-\mathrm{E}_{\max }(\%)$ and $\mathrm{EC}_{50}(\mathrm{M})$ values of $\mathrm{CaCl}_{2}$ in the absence (control) and presence of thymol $(3,9,27 \mathrm{and} 81 \mu \mathrm{g} / \mathrm{mL}) \mathrm{in}$ guinea pig ileum.

\begin{tabular}{|c|c|c|}
\hline LM-OE $(\boldsymbol{\mu g} / \mathbf{m L})$ & $E_{\max }(\%)$ & $\mathrm{EC}_{50}(\mathrm{M})$ \\
\hline Absence (control) & 100 & $8.1 \pm 0.2 \times 10^{-4}$ \\
\hline 3 & $99.1 \pm 4.8$ & $1.6 \pm 0.3 \times 10^{-3}$ \\
\hline 9 & $75.0 \pm 2.7 * \#$ & $3.7 \pm 0.5 \times 10^{-3}$ \\
\hline 27 & $33.4 \pm 4.7$ *\#\& & $1.4 \pm 0.3 \times 10^{-2}$ *\#\& \\
\hline 81 & $0^{* \# \gamma}$ & $\mathrm{Nd}$ \\
\hline
\end{tabular}

Data expressed as mean and S.E.M, respectively $\left(\mathrm{n}=5\right.$ ). ANOVA one-way followed by Tukey post-test: ${ }^{*} p<0.05$ (control $v s .9,27$ or 81 $\mu \mathrm{g} / \mathrm{mL}$ thymol); ${ }^{\#} p<0.05$ (9 $\mu \mathrm{g} / \mathrm{mL}$ thymol vs. $27 \mu \mathrm{g} / \mathrm{mL}$ thymol); ${ }^{*} p<0.05\left(27 \mu \mathrm{g} / \mathrm{mL}\right.$ thymol $v s .81 \mu \mathrm{g} / \mathrm{mL}$ thymol); ${ }^{\gamma} p<0.05(81 \mu \mathrm{g} / \mathrm{mL}$ thymol vs. $27 \mu \mathrm{g} / \mathrm{mL}$ thymol).

Source: Authors (2021).

\subsubsection{Effect of thymol on Cav1 channels}

Cumulative addition of thymol $(0.01-243 \mu \mathrm{g} / \mathrm{mL}, \mathrm{n}=5)$ over the tonic contraction relaxed $(p<0.05)$ the rat pulmonary artery pre-contracted with $\mathrm{S}-(-)$-Bay $\mathrm{K} 86440.3 \mu \mathrm{M}$ in a concentration-dependent manner $\left(\mathrm{E}_{\max }=98.8 \pm 1.2 \% ; \mathrm{EC}_{50}\right.$ $=10.6 \pm 2.0 \mu \mathrm{g} / \mathrm{mL}$ ) (Figure 7).

Figure 7 - Relaxant effect of thymol on pre-contracted isolated pulmonary artery rings with Phe $3 \mu \mathrm{M}(\bullet)$ or S-(-)-Bay K8644 $0.3 \mu \mathrm{M}(\diamond)$.

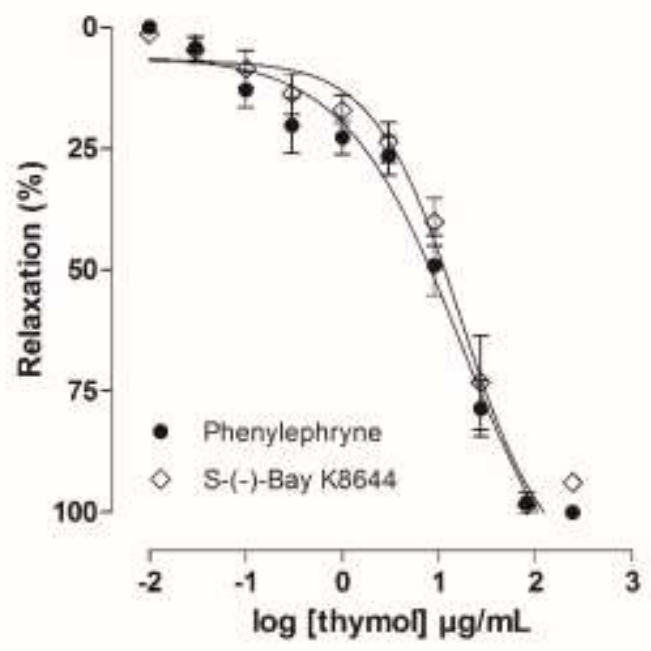

Data are expressed as the reverse percentage of maximal effect induced by phenylephrine or S-(-)-Bay K8644. Symbols and vertical bars represent the mean and S.E.M, respectively $(n=5)$.

Source: Authors (2021).

\subsubsection{Thymol activity in RhoA/Rho kinase (ROCK) pathway}

Thymol $(0.01-243 \mu \mathrm{g} / \mathrm{mL}, \mathrm{n}=5)$ relaxation curve was not altered in the presence of $\mathrm{Y}-276321 \mu \mathrm{M}\left(\mathrm{EC}_{50}=10.1 \pm 2.1\right.$ $\mu \mathrm{g} / \mathrm{mL}$ ), since the $\mathrm{EC}_{50}$ values did not differ to control (Figure 8, Table 2). 
Figure 8 - Relaxant effect of thymol on isolated rat pulmonary artery rings pre-contracted with Phe $3 \mu \mathrm{M}$ in both the absence (•) and presence of Y-27632(口).

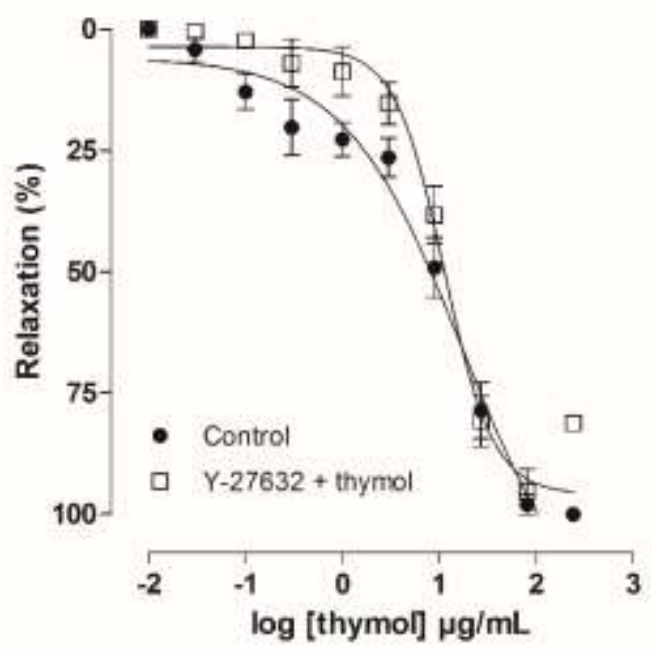

Data are expressed as the reverse percentage of maximal effect induced by phenylephrine. Symbols and vertical bars represent the mean and S.E.M, respectively $(\mathrm{n}=5)$.

Source: Authors (2021).

\section{Discussion}

In this work, initially was performed a pharmacological analysis of the vasorelaxant effect of the essential oil from Lippia microphylla Cham., as well as its two major compounds, thymol and carvacrol, in rat pulmonary artery. The mechanism of action of thymol, the most potent of those, was investigated as well, showing a dependence of endothelial relaxing factors release, but also evidencing a relaxant effect independent of endothelial factors. The mechanisms explored showed a positive modulation of endothelial muscarinic receptors itself or downstream proteins, and consequent prostanoids and/or NO release, possibly mediated by activation of adenylyl cyclase and protein kinase A pathway in these cells, or directly in smooth muscle. Moreover, it was showed an inhibitory effect on $\mathrm{Ca}^{2+}$ influx through $\mathrm{Ca} v 1$, that may be by direct or indirect mechanisms.

The chemical composition of LM-OE was previously determined (Xavier et al., 2011), presenting as the major constituents thymol (46.5\%), carvacrol (31.7\%), p-cymene (9\%), and $\gamma$-terpinene $(2.9 \%)$. Moreover, some pharmacological activities of LM-OE, thymol and carvacrol have been described, highlighting the vasorelaxant activity of carvacrol and thymol in rat thoracic aorta (Peixoto-Neves et al., 2010), and in guinea pig vena portae (Beer; Lukanov; Sagorchev, 2007). Despite this, the rationality of this study should be emphasized, which sought to investigate the relaxing effect of these compounds on the pulmonary artery, whose physiology differs in several aspects from that of the vessels in the systemic circulation, as discussed below.

Once thymol was more potent in relaxing the pulmonary artery when compared to LM-OE and carvacrol, and that the compound could be modulating endothelial factors, besides acting also in targets directly in smooth muscle, probably in higher concentrations, as it can be analyzed in the relaxant curves (Figure 1 and 2A-D, Table 1), we proceeded investigating which mechanisms would be involved in this effect.

It is well known that the ACh-induced relaxation response in blood vessels is mediated through the activation of endothelial muscarinic receptors and release of mediators, such as NO and $\mathrm{PGI}_{2}$ (Choy; Wong; Kwan, 2002; Norel et al., 1996). Thus, we evaluated the possible modulation of this pathway by thymol. Atropine, a non-selective muscarinic receptor antagonist (Choy; Wong; Kwan, 2002), attenuated the relaxant potency of this compound by about 4-fold, indicating that the monoterpene acts in this signaling pathway to promote the pulmonary artery relaxation (Figure 3 , Table 2). However, more 
investigations are needed to deeply explore this hypothesis, e.g., by molecular docking, in the perspective to find some modulable binding sites by thymol.

The chemical identification of the endothelium-derived relaxant factor, nitric oxide (NO), allowed a better understanding of important physiological processes, especially the cardiovascular system, such as the regulation of vascular tone and platelet function (Dias-Junior; Cau; Tanus-Santos, 2008). In this sense, it was possible to observe that the inhibition of endothelial NO production induced by the false substrate L-NAME to eNOS reduced the relaxant potency of the compound about 2-fold, suggesting that the relaxant effect of this compound on the rat pulmonary artery may involve the release of $\mathrm{NO}$ from endothelium (Figure 3, Table 2). Likewise, several terpenes have been described that have activities in different vascular beds by positively modulating the NO pathway, among them methyleugenol and $\alpha$-terpineol, in rat aorta (Magalhães et al., 2008), and $\alpha$-terpineol and citral, in rat superior mesenteric artery (Ribeiro et al., 2010; Moreira, 2013).

Prostanoids (e.g., $\mathrm{PGI}_{2}$ and $\mathrm{TXA}_{2}$ ) belong to the superfamily of eicosanoids, these being derivatives from arachidonic acid (AA) metabolism. Prostacyclin, or $\mathrm{PGI}_{2}$, is a member of the endogenous prostanoid family. In the pulmonary circulation, prostacyclin is released by the endothelial cells and is a potent endogenous vasodilator and inhibitor of platelet aggregation (Ruan et al., 2010).

According to this observation, we evaluated the possible action of thymol on the release of prostanoids, especially $\mathrm{PGI}_{2}$, to act in the pulmonary artery smooth muscle and induce relaxation. The inhibition of endothelial $\mathrm{PGI}_{2}$ precursor synthesis induced by the addition of indomethacin shifted the thymol concentration-response curve to the right about 4-fold, suggesting that the relaxant effect of this compound on rat pulmonary artery involves the release of this prostanoid (Figure 3 , Table 2). Furthermore, it is possible to observe that atropine and indomethacin were more able to reduce the thymol relaxant potency than L-NAME, indicating the major participation of the $\mathrm{M}_{3}-\mathrm{PLA}_{2}-\mathrm{PGI}_{2}$ than the NO pathway in the relaxant effect of the monoterpene. This may be explained by the fact that the NO signaling has not the great importance in regulating the pulmonary artery tonus as it has in the systemic circulation (Dias-Junior; Cau; Tanus-Santos, 2008).

The prostacyclin released by the endothelium activate its IP receptors in the smooth muscle cell, which couples to $\mathrm{G}_{\mathrm{s}}$ protein and then activates adenylyl cyclase (AC), increasing cytosolic levels of cAMP that has been widely implicated in the control of pulmonary vascular tone (Hall, 2000; Sobolewski et al., 2004). After activation of AC, this enzyme will perform the conversion of ATP into cAMP, which, in turn, is a second messenger that produces the most diverse biological responses, where the activation of PKA is one of its most important targets (Billington; Hall, 2012). PKA is a key enzyme for the maintenance of tonus in the vascular smooth muscle, since it phosphorylates several cellular targets culminating in the decrease in the cytosolic $\mathrm{Ca}^{2+}$ concentration with consequent relaxation of this muscle (Chen et al., 2011).

In this context the AC inhibitor, IPA, displaced the relaxation curve of thymol to the right, with the reduction of the relaxant potency by approximately 3 -fold, in addition to a decrease in its efficacy. Moreover, in the presence of the PKA inhibitor, H-89, the relaxation curve of thymol was attenuated by approximately 2-fold, but with no change in efficacy (Figure 4, Table 2). These results corroborate the previous results, thus confirming the positive modulation of the IP/AC/PKA pathway in the relaxant effect of thymol in rat pulmonary artery. Furthermore, in view the participation of this pathway in the release of endothelium-derived relaxant factors, such as prostanoids and NO, as previously discussed, we arise the possibility that thymol is activating $\mathrm{AC} / \mathrm{PKA}$ in both endothelium and smooth muscle to lead pulmonary artery to relax.

Knowing that smooth muscle contractility depends on regulated changes in intracellular $\mathrm{Ca}^{2+}$ concentration, and that changes in the conduction of potassium ions through the plasma membrane influence the $\mathrm{Ca}^{2+}$ influx, we evaluated the possibility of thymol be modulating $\mathrm{K}^{+}$or $\mathrm{Ca}^{2+}$ channels.

For this, the organ was contracted with 30 or $80 \mathrm{mM} \mathrm{KCl}$, wherein in the first condition partial blockage of the $\mathrm{K}^{+}$ ions efflux occurs (Clark; Fuchs, 1997), while in the second will occur a greater blockade of $\mathrm{K}^{+}$efflux. It is known that 
substances that promote relaxation for activation of $\mathrm{K}^{+}$channels are less effective in relaxant in the second condition, since the electrochemical gradient of $\mathrm{K}^{+}$difficulties the efflux of this ion and the smooth muscle relaxation (Gurney, 1994; Somlyo; Somlyo, 2003).

There was no difference in both the efficacy and potency of thymol when the pulmonary artery was contracted with 30 or $80 \mathrm{mM} \mathrm{KCl}$, thus indicating that thymol would not be activating $\mathrm{K}^{+}$channels to exert its relaxant effect but inhibiting the $\mathrm{Ca}^{2+}$ influx through $\mathrm{Cav}$ channels (Figure 5). Confirming this hypothesis, we observed that the $\mathrm{CaCl}_{2}$ contraction curves were displaced to the right in a non-parallel manner, with a reduction in both the efficacy and potency of the contractile agent (Figure 6, Table 3). Thus, these results confirm the hypothesis previously suggested that thymol is also exerting its vasodilatory effect in pulmonary artery by inhibiting the $\mathrm{Ca}^{2+}$ influx through the $\mathrm{Cav}$. Also, it is likely that the inhibition of $\mathrm{Ca}^{2+}$ influx may be occurring at higher concentrations of the monoterpene, since there was overlap of thymol relaxation curves on both intact and denuded endothelium.

The Cav were initially classified as $\mathrm{L}, \mathrm{N}, \mathrm{P} / \mathrm{Q}, \mathrm{R}$ and $\mathrm{T}$ depending on some electrophysiological and pharmacological properties (Catterall, 2011). In the smooth muscle in general, the Cav1 (L type) are the best characterized and the main responsible for the $\mathrm{Ca}^{2+}$ entry during contraction (Knot; Brayden; Nelson, 1996). We observed that thymol significantly and concentration-dependently relaxed the pulmonary artery contracted with the dihydropyridine S-(-)-Bay K8644. Additionally, the relaxant potency of the monoterpene was the same when the organ was contracted with Phe (Figure 7), indicating that thymol acts in the common step of both contractile agents, in this case, the Cav1, to exert its vasorelaxant effect on pulmonary artery.

The main pathway of $\mathrm{Ca}^{2+}$ sensitization is mediated by the small RhoA monomeric $\mathrm{G}$ protein and its Rho kinase target (ROCK). Recent studies have shown that inhibition of ROCK virtually normalizes high pressure and resistance of the pulmonary artery (AP) in rats with pulmonary arterial hypertension (Nagaoka et al., 2004). It is known that this pathway can be activated by GPCR signaling or by $\mathrm{Ca}^{2+}$ influx through $\mathrm{Ca}_{\mathrm{v}}$, indicating a common signaling route for either GPCR agonists, such as Phe, or for $\mathrm{Cav}_{\mathrm{v}}$ openers, as $\mathrm{KCl}$ and dihydropyridines. Moreover, thymol at $27 \mu \mathrm{g} / \mathrm{mL}$ reduced the $\mathrm{Ca}^{2+}$ sensitivity in pulmonary artery, as shown by the reduced potency of $\mathrm{CaCl}_{2}$ in contract the organ.

Thus, we imply that thymol might be inhibiting this signaling pathway to exert its vasodilatory effect on pulmonary artery. In the presence of the ROCK blocker, Y-27632, there was no change in the thymol relaxant efficacy and potency, thus suggesting that this pathway is not involved in the relaxant effect of thymol in pulmonary artery (Figure 8).

\section{Conclusion}

The essential oil from Lippia mycrophylla Cham., as well as its two major compounds, thymol and carvacrol, presents vasorelaxant effect in rat pulmonary artery, and the thymol mechanism of action involves the release of NO and relaxing prostanoids from endothelium and/or direct activation of AC/PKA pathway on smooth muscle, as well as the inhibition of $\mathrm{Ca}^{2+}$ influx through Cav1, specially at higher concentrations. These data provide some new pharmacological evidence for the modulatory effect of thymol on the pulmonary vascular tone and its possible further application as an alternative for the treatment of diseases affecting the pulmonary vasculature, as pulmonary arterial hypertension.

Therefore, in the perspective as a new drug for pulmonary hypertension treatment, further studies in animal model of this disease are needed to explore this hypothesis.

\section{Acknowledgments}

The authors would like to thank for Universidade Federal da Paraíba (UFPB), José Crispim Duarte and Luís C. Silva 
for providing technical assistance, and Conselho Nacional de Desenvolvimento Científico e Tecnológico (CNPq) and Coordenação de Aperfeiçoamento de Pessoal de Nível Superior (CAPES), for the financial support.

\section{References}

Agra, M. F., Freitas, P. F., \& Barbosa-Filho, J. M. (2007). Synopsis of the plants known as medicinal and poisonous in Northeast of Brazil. Revista Brasileira de Farmacognosia, 17, 114-140.

Alencar, A. K. N., Pereira, L. S., Silva, F. E. et al. (2013). A novel adenosine $A_{2 a}$ receptor agonist attenuates the progression of monocrotaline-induced pulmonary hypertension in rats. Pulmonary \& Respiratory Medicine, 4, 1-6.

Beer, A. M., Lukanov, J., \& Sagorchev, P. (2007). Effect of Thymol on the spontaneous contractile activity of the smooth muscles. Phytomedicine, 14, 65-69.

Billington, C. K., \& Hall, I. P. (2012). Novel cAMP signalling paradigms: therapeutic implications for airway disease. British Journal of Pharmacology, 166, 401-410.

Boskabady, M. H., Jafari, Z., \& Pouraboli, I. (2011). The effect of carvacrol on muscarinic receptors of guinea-pig tracheal chains. Phytotherapy Research, 25, 530-535.

Catterall, W. A. (2011). Structure and regulation of voltage-gated $\mathrm{Ca}^{2+}$ channels. Annual Review of Cell and Developmental Biology, 16, 521-555.

Chen, I. S., Dai, Z. K., Welsh, D. G. et al. (2011). Protein kinases modulate store-operated channels in pulmonary artery smooth muscle cells. Research Journal of Biological Sciences, 18, 1-12.

Choy, W. Y., Wong, Y. F., \& Kwan, Y. W. (2002). Role of mitogen-activated protein kinase pathway in acetylcholine-mediated in vitro relaxation of rat pulmonary artery. European Journal of Pharmacology, 434, 55-64.

Clark, S. G., \& Fuchs, L. C. (1997). Role of Nitric Oxide and $\mathrm{Ca}^{++}$-Dependent $\mathrm{K}^{+}$Channels in Mediating Heterogeneous Microvascular Responses to Acetylcholine in Different Vascular Beds. Journal of Pharmacology and Experimental Therapeutics, 282, 1473-1479.

Dias-Junior, C. A., Cau, S. B. A., \& Tanus-Santos, J. E. (2008). Papel do óxido nítrico na regulação da circulação pulmonar: implicações fisiológicas, fisiopatológicas e terapêuticas. Jornal Brasileiro de Pneumologia, 34, 412-419.

Furchgott, R. F., \& Zawadzki, J. V. (1980). The obligatory role of endothelial cells in the relaxation of arterial smooth muscle by acetylcholine. Nature, 288, 373-376.

Gao, Y., Portugal, A. D., Negash, S. et al. (2007). Role of Rho kinases in PKG-mediated relaxation of pulmonary arteries of etal lambs exposed to chronic high altitude hypoxia. American Journal of Physiology. Lung Cellular and Molecular Physiology, 292, 678-684.

Greyson, C. R. (2010). The Right Ventricle and Pulmonary Circulation: Basic Concepts. Revista Española de Cardiología, 63, 81-95.

Gurney, A. M. (1994). Mechanisms of drug-induced vasodilation. Journal of Pharmacy and Pharmacology, 46, 242-251.

Hall, I. P. (2000). Second messengers, ion channels and pharmacology of airway smooth muscle. European Respiratory Journal, 15, $1120-1127$.

Huang, W., Yen, R. T., Mclaurine, M. et al. (1996). Morphometry of the human pulmonary vasculature. Journal of Applied Physiology, 81, 2123-2133.

Jeffery, T. K., \& Wanstall, J. C. (2011). Pulmonary vascular remodeling in hypoxic rats: effects of amlodipine, alone and with perindopril. European Journal of Pharmacology, 416, 123-131.

Karasu-Minareci, E., Ozbudak, I. H., Ozbilim, G. et al. (2011). Acute Effects of Vardenafil on Pulmonary Artery Responsiveness in Pulmonary Hypertension. Scientific World Journal, 12, 1-6.

Knot, H. T., Brayden, E. J., \& Nelson, M. T. (1996). Calcium channels and potassium channels. In: Bárány M (ed). Biochemistry of smooth muscle contraction. Elsevier Inc., 203-219.

Lau, E. M., Giannoulatou, E., Celermajer, D. S. et al. (2017). Epidemiology and treatment of pulmonary arterial hypertension. Nature Reviews Cardiology, 14, 603.

Magalhães, P. J., Lahlou, S., Jucá, D. M. et al. (2008). Vasorelaxation induced by the essential oil of Croton nepetaefolius and its constituents in rat aorta are partially mediated by the endothelium. Fundamental and Clinical Pharmacology, 22, 169-177.

Marques, A. J., \& Filgueiras, C. A. L. (2009). O químico e o naturalista luso-brasileiro Alexandre Antonio Vandelli. Quimica Nova, 32, $2492-2500$.

Moreira, F. V. (2013). Efeitos cardiovasculares do citral, monoterpenos majoritário do óleo essencial de Cymbopogon citratus, em ratos. Thesis (PhD in Health Sciences): Federal University of Sergipe.

Nagaoka, T., Morio, Y., Casanova, N. et al. (2004). Rho/Rho kinase signaling mediates increased basal pulmonary vascular tone in chronically hypoxic rats. American Journal of Physiology. Lung Cellular and Molecular Physiology, 287, 665-672.

Norel, X., Walch, L., Costantino, M. et al. (1996). M1 and M3 muscarinic receptors in human pulmonary arteries. British Journal of Pharmacology, 119, 149-157. 
Research, Society and Development, v. 10, n. 4, e29010413971, 2021

(CC BY 4.0) | ISSN 2525-3409 | DOI: http://dx.doi.org/10.33448/rsd-v10i4.13971

Pauvert, O., Lugnier, C., Keravis, T. et al. (2003). Effect of sildenafil on cyclic nucleotide phosphodiesterase activity, vascular tone and calcium signaling in rat pulmonary artery. British Journal of Pharmacology, 139, 513-522.

Peixoto-Neves, D., Silva-Alves, K. S., Gomes, M. D. M. et al. (2010). Vasorelaxant effects of the monoterpenic phenol isomers, carvacrol and thymol, on rat isolated aorta. Fundamental and Clinical Pharmacology, 24, 341-350.

Rees, D. D., Palmer, R. M. J., Schulz, R. et al. (1990). Characterization of three inhibitors of endothelial nitric oxide synthase in vitro and in vivo. British Journal of Pharmacology, 101, 746-752.

Ribeiro, T. P., Porto, D. L., Menezes, C. P. et al. (2010). Unravelling the cardiovascular effects induced by $\alpha$-terpineol: A role for the nitric oxide-cGMP pathway. Clinical and Experimental Pharmacology and Physiology, 37, 811-816.

Rodrigues, F. F. G., Coutinho, H. D. M., Campos, A. R. et al. (2011). Antibacterial activity and chemical composition of essential oil Lippia microphylla Cham. Acta Scientiarum. Biological Sciences, 33, 141-144.

Rodríguez-Ramos, F., González-Andrade, M., \& Navarrete, A. (2011). Gnaphaliin A and B relax smooth muscle of guinea-pig trachea and rat aorta via phosphodiesterase inhibition. Journal of Pharmacy and Pharmacology, 63, 926-935.

Ruan, C. H., Dixon, R. A. F., Willerson, J. T. et al. (2010). Prostacyclin Therapy for Pulmonary Arterial Hypertension. Texas Heart Institute Journal, 37, 391399.

Sherwin, C. M., Christiansen, S. B., Duncan, I. J. et al. (2003). Guidelines for the ethical use of animals in applied ethology studies. Applied Animal Behaviour Science, 81, 291-305.

Singhal, S., Henderson, R., Horsfield, K. et al. (1973). Morphometry of the human pulmonary arterial tree. Circulation Research, 33, $190-197$.

Sobolewski, A., Jourdan, K. B., Upton, P. D. et al. (2004). Mechanism of cicaprost-induced desensitization in rat pulmonary artery smooth muscle cells involves a PKA-mediated inhibition of adenylyl cyclase. American Journal of Physiology. Lung Cellular and Molecular Physiology, 287, 352-359.

Somlyo, A. P., \& Somlyo, A. V. (2003). $\mathrm{Ca}^{2+}$ sensitivity of smooth muscle and non-muscle myosin II: modulated by G proteins, kinases, and myosin phosphatase. Physiological Reviews, 83, 1325-1358.

Sommer, N., Ghofrani, H. A., Pak, O. et al. (2021). Current and future treatments of pulmonary arterial hypertension. British Journal of Pharmacology, 178, 6-30.

Subramani, J., Leo, M. D. M., \& Kathirvel, K. (2010). Essential role of nitric oxide in sepsis-induced impairment of endothelium-derived hyperpolarizing factor-mediated relaxation in rat pulmonary artery. European Journal of Pharmacology, 630, 84-91.

Wang, Y., Gharahi, H., Grobbel, M. R. et al. (2021). Potential damage in pulmonary arterial hypertension: An experimental study of pressure-induced damage of pulmonary artery. Journal of Biomedical Materials Research Part A, 109, 579-589.

Xavier, A. L., Pita, J. C. L. R., Brito, M. Y. et al. (2011). Chemical composition, antitumor activity, and toxicity of essential oil from the leaves of Lippia microphylla. Zeitschrift für Naturforschung, 70, 129-137.

Zahid, K. R., Raza, U., Chen, J. et al. (2020). Pathobiology of pulmonary artery hypertension: role of long non-coding RNAs. Cardiovascular research, 116, 1937-1947.

Zhang, S., Liu, Y., Guo, S. et al. (2010). Vasoactive intestinal polypeptide relaxes isolated rat pulmonary artery rings through two distinct mechanisms. Journal of Physiological Sciences, 60, 389-397. 